\title{
A CASE PRIMARY HYPOTHYROIDISM: LINGUAL THYROID
}

\section{PRIMMER HIPOTIROİDILİ BİR OLGU:LINGGAL TİROID}

Yasin ÖZTÜRK ${ }^{1}$,Şenay ARIKAN DURMAZ ${ }^{2}$, Yunus İlyas KİBAR ${ }^{1}$, Ahmet TAY ${ }^{1}$, Mehmet Emin AYHAN ${ }^{1}$

${ }^{1}$ Erzurum Region Training and Research Hospital, Department of Internal Medicine

${ }^{2}$ Erzurum Region Training and Research Hospital, Department of Endocrinology and Metabolism

Yasin Öztürk MD .- yozturk29@gmail.com

Şenay ARIKAN DURMAZ MD. Associate Prof. -sarikan822@gmail.com

Yunus İlyas Kibar MD. -yunusilyas@gmail.com

Ahmet Tay MD. - dr.atay@hotmail.com

Mehmet Emin Ayhan MD. - m.eminayhan@ hotmail.com

Short Running Title: Lingual Thyroid

Correspondence Address: yozturk29@gmail.com

Phone: +9005056733242 


\begin{abstract}
Lingual thyroid is an abnormal formation appearing as the result of a deficient descent of the thyroid gland to its normal pretracheal location through the thyroglossal duct during embryological development and its a rare embryological aberration. A 19 years old woman was admitted our hospital with the compliants of swallowing difficulty, froeign-bodyfeeling in her throat,swelling at the back of the tongue, deepining of her voice and constipation. Her phycical examination showed a spherical, red, flesy mass with regular contour located at the back of the tongue While thyroid scan with tecnetium $99 \mathrm{~m}$ revealed isotop uptake at the base of the tongue, no uptake was detected at the normal location of the thyroid gland. According to these findings the diagnosis of lingual tyhroid was detected. The surgical excision of the mass was not appropriate treatment since the lingual thyroid was the only functioning throid tissue and medical treatment was recommended.We aimed at presenting a case of lingual thyroid and hypothyroidsm along with laboratory ad imaging findings.
\end{abstract}

Keywords: Lingual thyroid, primer hypothyroidism, thyroid scyntigraphy

\title{
ÖZET
}

Lingual tiroid, tiroidin embriyolojik gelişlimi esnasında tiroglossal kanalın pretrakeal lokalizasyonuna inmesi sırasında oluşan yetersizlik sonucu görülen, nadir bir embriyolojik anomalidir. Ondokuz yaşında bir bayan yutkunma güçlüğü, boğazda yabancı cisim hissi, dil arkasında şişlik, kabızlık, seste kalınlaşma şikayetleri ile başvurdu. Fizik muayenesinde dil arkasında küre şeklinde kırmızı düzgün yüzeyli kitle izlendi. Primer hipotiroidi tanısı konulan hastada Technetium $99 \mathrm{~m}$ ile tiroid bezi sintigrafik olarak incelendiğinde tiroid bezinin normal lokalizasyonunda izotop tutulumu olmayıp, dil tabanında olduğu görüldü. Bu bulgularla lingual tiroid tanısı konuldu. Hastada tek fonksiyonel tiroid dokusu bu olduğu için cerrahi eksizyon yerine medikal tedavi uygun görüldü. Bu yazımızda hipotirodizm bulguları olan lingual tiroidli olguyu labaratuar ve görüntüleme bulguları ile sunmayı amaçladık.

Anahtar kelimeler: Lingual tiroid, primer hipotirodizm, tiroid sintigrafisi 


\section{INTRODUCTION}

Thyroid gland develops from a medial embryonic thyroid primordium and a smaller pair of lateral ambryonic thyroid primordial. Lateral thyroid primordia do not contribute to the development of the thyroid follicles but give rise to calcitonin producing parafolliculer $\mathrm{C}$ cells.Medial primordium develops as an endodermal diverticle in the ventral midline of the pharynx between the primary and secondary phrangeal pouches and become distinguishable by the end the third week of pregnancy.This diverticle lobulates, contitutes two lobules and these two lobules connect to each other through a tube called thyroglossal duct at the point where they arise from pharynx. The pharyngeal connection of the thyroglossal duct is in the ventral phraynx where the tongue formation occurs. Thyroid primordium follows the route of the thyroglossal duct and passes anterior to hyoid bone to descend its normal location.By the end of the seventh week thyroid takes a concentric shape and locates in front of the developing trachea. During this period of time the lumen of the duct closes off and becomes astalk-like attachment and the pharyngeal attechment point of the duct appears as foremen coceum at the tip of sulcus terminalis on the dorsum tongue $(1,2)$. The abnormalities related to the descent from the foramen caceum are responsible fort he ectopic thyroid tissue. This rare embryologic pathology is the lingual thyroid formed in foremen in coecum (3).

In $75 \%$ of the cases of lingual thyroid, the only functioning thyroid tissue in the body is found as this ectopic tissue (4). The first known case of lingual thyroid was presented by Hickmann in 1869 (5). The prevalence of lingual tyhroid was reported as 1 per 100000 people (6). Autopsy studies have determined highprevalence since most of the cases remain asymptomatic (7). Lingual thyroid may enlarge and becomes symptomatic in certain conditions such as pregnancy, thyrotoxicosis and neoplasia (8). We aimed at presenting this rare case of symptomatic lingual tyhroid along with radiological and scintigraphic findings and a literature review. 


\section{CASE REPORT}

When a 19 years old woman was admitted to the otorhinolaryngology outpatient clinic. With the compliants of gradually increasing sensation ofa catch in her throat when swallowing, foreign-body-feeling in her throat, swelling at the back of the tongue, deepining of her voice and constipation, ypothyroidsm was suspected the patient was referred to the endocrinology outpatient clinic.In her assesment in our outpatient clinic, the patient particularly complained of recently developed constipation, deepening of her voice and gradually increasing sensation of a catch in her throat.

A short stature attracted attention in her physical examination (Height: $152 \mathrm{~cm}$, body weight $69 \mathrm{~kg}$. Body mass index: 29.4). In the examination for the short stature, the height was found below the 25th percentile and -2SD for sex and age. A menial and motor retardation attracted attention. The thyroid gland could not be palpated during the thyroid gland examination.other systems examination revealed no abnormality and the patient's skin was pale and dry . No hair loss was detected. A spherical, red lesion with regular contour, $2 \times 2 \times 1$ $\mathrm{cm}$ in dimensions was observed when a more detailed endoscopic examination of the mass was performed (Figure 1-2).

In the laboratory examinations hemoglobin level was found as $12.1 \mathrm{mg} / \mathrm{dl}$, Hematocrit was found as 35.2\%, the PLT count was 197 000/ul, serum levels of FT3 was 0.61 pg/mL(N:2,15.2). FT4 was $0.15 \mathrm{ng} / \mathrm{dl} .(0,8-1,76)$, and $\mathrm{TSH}$ was $>150 \mathrm{mIU} / \mathrm{L}(0,3-4,9)$. Both anti-thyroid peroxidase antibody which is one of the thyroid antibodies [16IU/ml, (N: 0-35)] and antithyroglobin antibody $[<20 \mathrm{lU} / \mathrm{ml}(\mathrm{N}: 0-40)]$ were found negative and these results were consistent with primary hypothyroidism. Consequently, the ultrasound examination of the thyroid gland was performed. The echo pattern of thyroid parenchyma was not identified at the thyroid location (Figure3).

Ectopic thyroid gland was considered and a thyroid scintigraphy with Tc99m was carried out Thyroid scintigraphy with Tc99m revealed a homogenous focal activity uptake in a region consistent with tongue base. No activity uptake consistent with thyroid tissue was observed in the thyroid lodge (Figure4).A diagnosis of lingual thyroid was made according to these findings that suggested a hypofunctioning ectopic thyroid tissue at sublingual location. Surgical excision of the ectopic thyroid was not recommended to the patient since although hypofunctioning, it was the only functioning thyroid tissue in the body and it was giving rise to mild symptoms. A thyroid hormone suppression therapy was started to the patient in order 
to reduce the mass causing a foreign body sensation in her throat and symptomatic hypothyroidism and outpatient follow up was recommended to the patient.

\section{DISCUSSION}

The thyroid gland is the first endocrine gland to develop during the embrionic period (9). Embryonic origin of the thyroid gland is the foramen cecum located at he junction of $2 / 3$ anterior and 1/3 posterior parts of the longue. During the embryonic development, the thyroid tissue descend to its normal pretracheal location passing through the thyroglossal duct (10). As in our case. the most common ectopic thyroid tissue location is the tongue root just behind the foramen coecum. accounting for $90 \%$ of the cases of ectopic thyroid (11).Our other two adolescent eases of lingular thyroid were previously described by Arikan et al $(12,13)$. The first prominent feature that attracted attention in these two cases was the retardation of the development. However, cases of ectopic thyroid with mediastinal,cardiac, esophageal or diaphragmatic locations were also reported (14). Ectopic thyroid tissue may be either functioning or non fonctioning and is 7 times more common in females than in male

Ectopic thyroid attracts attention during periods when the increased amount of hormone is required, such as in puberty, pregnancy, menopause (8). RelativeJv insuficient levels ol thyroid hormone lead to increased TSH secretion during these periods. This situation consequently results in the enlargement of the ectopic thyroid gland and may render it symptomatic (15).

Ectopic lingual thyroid may cause symptoms such as foreign body sensation in throat, dysphagia, dysphonia and dyspnea, it may mimic a lingual tumor or may be asymptomatic (16).In our case, swallowing difficulty, foreign body sensation in the throat and deepening of the voice were present for a long period of lime. Hypothyroidism has been reported in to $33 \%$ of the cases of lingual thyroid (17). The hormone levels of our case were also consistent with hypothyroidism.

Lingual thyroid appears as mass with regular contour and homogeneous structure and is more echogenic compared to the tongue muscles in ultrasound examination.When the ectopic thyroid tissue enlarges or a nodule, cyst or tumor develops within the ectopic thyroid tissue, the homogeneous echogcnic structure disappears and findings related to these lesions arc detected (18). Due to the different signal characteristics of the colloidal material, (the lingual thyroid is observ ed as a nonhomogeneouse structure in Magnetic Resonance Imaging examination. If there is no enlargement of the tissue, nodule or tumor formation within the ectopic thyroid tissue. 
it is observed as isointense or mildly hyperintense in comparison to to longue muscles on T1 weighted sequences and hyperintens comparison to the tongue muscles on T2 weighted sequences (19). Scintigraphic examination reveals similar activities in ectopic thyroid tissue and thyroid tissue at the normal location (19). Mostly no activity is detected at the normal location. In our case, while no activity was detected at the normal pretracheal location, thyroid activity was demonstrated at the tongue root.

The determination of the treatment to cases diagnosed with lingual tyhroid depends on several factors such as the dimensions of the mass, te presence of local symptoms, the age of the patient the state of the thyroid gland, ulceration, hemorrhage, cystic degeneration of malignancy. Suppression therapy may provid prominen regression if the clinical symptoms are not present. The indications of surgical excision generally include severe or recurrent hemorrhage, gland enlargement causing dysphagia, prominent airway stenosis, suspicion of malignancy and dysphonia (20). Radioiodine therapy is preserved for elderly patient who are not suitable for surgery and it is contraindicated in younger patients since it may cause damage in gonads and other organs(21). Surgical removal of lingual thyroid may be performed through transoral, transhyoid routes or through a lateral pharyngotomy approach using external neck incision. Transoral approach is appropriate for smaller lesions. The disadvantages of the transoral approach include limited vision, not always being able to perform a complete bleeding control in spite of the possibility of a life threatening hemorrhage. However unlike the aforementioned approaches, the lower risks of damage to vital structures in the neck, fistula formation, deep neck infection and less apparent scar are included to the advantages of this technique (2).

Thyroid hormone suppression therapy was found appropriate in our case since she was young, the only functioning thyroid tissue in the body was the lingual thyroid tissue and other surgical indications were absent .Although lingual thyroid is not a common lesion.We should be kept in mind when a mass at the tongue root is detected in the midline in particular and surgical intervention tor the undiagnosed lesions may result in the removal of the only functioning thyroid tissue in the body. We should be used as a first step examination tool and scintigraphic examination should be used to confirm the diagnosis.

\section{REFERENCES}


1. Todd NW. Common congenital anomalies of the neck. Embryology and surgical anatomy. Surg Clin North Am. 73(4):599-610, 1993

2. Akçam T, Atalay A, Gerek M, Özkaptan Y. Lingual Tiroidde Disfaji: Olgu Sunumu [Dysphagia Due To Lingual Thyroid: Case Report]. KBB ve BBC Dergisi, 12 (1): 1620,2004

3. Wertz ML. Management of undescend lingual subhyoid thyroid glands. Laryngoscope. 84(4):507-521, 1974

4. Skolnik EM, Yee KF, Golden $\mathrm{T}$ A. Transposition of the lingual thyroid. Laryngoscope. 86 (6) :785-791, 1976

5. Weider DJ, Parker W. Lingual thyroid, Ann Otol. 86(6 pt 1) :841-8, 1977

6. Douglas PS, Baker AW. Lingual thyroid. Br J Oral Maxillofac Surg.32(2):123-4. 1994

7. Katılmış H, Sezgin K, Çallı Ç, Özdemir İ, Öztürkcan S. Lingual Tiroid Transpozisyonu.[ Transposition Of Lingual Thyroid]. T Klin J E N T 3(4):4043,2003

8. Kamat MR, Kulkami IN, Desai PB, Jussawalle DJ. Lingual thyroid. Br. J. Surgery. 66 (8): 537-539,1979

9. Buckland R.W , Pedley J. Lingual thyroid- a threat to the airway. Anaesthesia. 55(11) : 1103-1105, 2000.

10. Quarracino M, Aguas S. Lingual thyroid: a clinical case. Med Oral. 8(1) :57-60, 2003.

11. Smoker W.R.K. Oral Cavity. In Som P.M, Curtis H.D. Head and Neck Imaging. 3rd edn St Louis:Mosby. 488-544, 1996

12. Arıkan S, Gökalp D, Tuzcu A, Bahceci M, Bahceci S. An Embryological Cause of Primer Hypothyroidism, Lingual Thyroid. Turkish Journal of Endocrinology and Metabolism, 2: 49-52,2006

13. Pasa S., Beyaz C., Arikan S., Altintas A., Gokalp D. ,Cil T., Tuzcu A., Bahceci M. Ectopic Lingual Thyroid as a Rare Cause of Primary Hypothyroidism: A Case Report. Endocrinologist: - 18(4) : 163-164, 2008

14. Sauk JJ Jr. Ectopic lingual tyhroid. J Pathol.102(4): 239- 243, 1970

15. Farrel M, Forrer M. Ungual thyroid. Aust. N. Z. J. Surgery; 123-124,1994

16. Özahinolu C, Akçalı Ç, Kırolu F, Kanlıkama M, Özmen H. Lingual tiroidler. Türk Otolarengoloji Arşivi. 25(4): 199-205, 1987.

17. Prasad KC, Bhat V. Surgical management of lingual thyroid: a report of four cases. $\mathrm{J}$ Oral Maxillofac Surg. 58(2):223-7, 2000 
18. Miller JH. Lingual thyroid: Sonografic appearance. Radiology. 156(1): 83-5, 1985

19. Giovagnorio F, Cordier A, Romeo R. Lingual thyroid: value of integrated imaging. Eur Radiol.6(1) :105-7,1996

20. Chiu TT, Su CY, Hwang CF, Chien CY, Eng HL. Massive bleeding from an ectopic lingual thyroid follicular ade- noma during pregnancy. Am J Otolaryngol. 23(3):1858,2002

21. Gallo A, Leonetti F, Torri E, Manciocco V, Simonelli M, DeVincentiis M. Ectopic lingual thyroid as unusual cause of severe dysphagia. Dysphagia 16(3):220-3, 2001 